\title{
Impact of the Work on the Academic Performance of the Students of Higher Education of the Autonomous University of Guerrero, México
}

\author{
María del Rocío García Sánchez ${ }^{1}$, Guadalupe Godínez Alarcón ${ }^{2}$, Joaquín Reyes Añorve ${ }^{1}$ \\ ${ }^{1}$ School of Law of Acapulco, the Autonomous University of Guerrero, Acapulco, México \\ ${ }^{2}$ School of Psychology, the Autonomous University of Guerrero, Acapulco, México
}

Email address:

mrociogsz@yahoo.com.mx (M. del R. G. Sánchez), cenself12@hotmail.com (G. G. Alarcón), joaquin.reyes94@yahoo.com.mx (J. R. Añorve)

\section{To cite this article:}

María del Rocío García Sánchez, Guadalupe Godínez Alarcón, Joaquín Reyes Añorve. Impact of the Work on the Academic Performance of the Students of Higher Education of the Autonomous University of Guerrero, México. Higher Education Research.

Vol. 3, No. 5, 2018, pp. 92-99. doi: 10.11648/j.her.20180305.12

Received: October 24, 2018; Accepted: November 16, 2018; Published: December 26, 2018

\begin{abstract}
The economic crisis in which Mexico finds itself and before the fall of the purchasing power of the salary, it has become necessary to increase the economic income in each family, for what the students see in that need to work to be able to sustain their studies and / or contribute to family expenses. Among the countries of Latin America, Mexico is the country that occupies the first place in school dropout, therefore, it has been important to analyze the impact of the workday on the academic performance of 3rd and 4th grade students of Psychology Schools, Law-Acapulco, Sociology and Tourism of the Autonomous University of Guerrero because this impact can be a factor of desertion. The establishment of the methodology of descriptive and correlational research served to expose the reality in the academic performance of working students, through the application of a survey as a research procedure that allowed us to obtain and develop data quickly and effectively. 371 surveys were applied among the four schools selected for this study. The main consequence was that the workday impacts the academic performance of the students in different ways such as: the time they spend studying, the time they spend to complete their tasks and academic work, as well as the stress that this causes them.
\end{abstract}

Keywords: Workday, Performance, Academic Performance, Stress

\section{Introduction}

Youth divine treasure, in which moment we lose young people between work and school, which is represented in the low academic performance, every day and due to the economic crisis that Mexico is going through, the figures of students who study and work in higher education institutions they are getting higher. Thus, at the beginning of the school year the student has to face a new beginning, classes, homework, exams, the family and the need to find and find a job to help them meet the expenses that their education generates, the long hours of work, low wages, few or no social security benefits, instability or job threat, cause stress, fatigue and anxiety, developing an emotional disability that occurs when being in a space where they do not feel well, where they do not they feel included and usually have a reactive reaction to external stimuli and the conditions that are evidently made by inauthentic and disgusted beings because they do not have the capacity to create a space within the school and work that makes them feel safe.

Consequently, students reach a decline in their academic performance, the culture that was required, compliance, study and enjoyment is ending. The economic crises that we are experiencing are causing more and more abandonment in the classrooms due to absences and, consequently, desertion. Mexico is the country occupies the first place in school dropout, among the countries of Latin America, according to the report "Youth: Realities and challenges for a development with equality" of the Economic Commission for Latin America and the Caribbean (ECLAC). [1].

Obviously ECLAC indicates that the countries with the highest dropout rates also register a marked gap between 
higher and lower income households, which is why young people who start their higher education studies have the need to look for a job. The Ministry of Public Education in Mexico considers school desertion as: the abandonment of school activities before finishing an educational degree. [2].

The ILO [3] shows how the crisis has brought with it the inevitable increase in the levels of inequality and poverty in the first decade of the 21 st century. To account for this, the United Nations Development Program noted in its report that 10 of the 15 most unequal countries in the world are located in Latin America. Latin America and the Caribbean, being Mexico one of them and in which inequality became more evident, to the extent that the income of the richest $10 \%$ went from being 19.3 times greater than that of the poorest $10 \%$ in 1984 , to 33.5 times in 2008 .

The economic crisis in which Mexico finds itself and before the fall of the purchasing power of the salary, it has become necessary to increase the economic income in each family. It is precisely young people who decide to work to contribute to family spending, to sustain their careers or to satisfy a level of consumption that their parents can not provide. But also, when young people have a job, in some cases, this is of poor quality, either because of their long working hours (more than eight hours a day) because of the lack of social protection or because they have a job where they receive economic income lower than the cost of a food basket, which places them in a situation of labor poverty.

The crisis situation that exists on the planet in general is a problem of lack of time and organization, there are difficult and distressing days where stress takes over people and actions are carried out that are not recognized or that you want to avoid, because there are deficiencies for the development and expansion of consciousness, you can have a job or be doing studies that most do not recognize, so it is necessary to make changes in behavior, changing needs and establish secondary needs to have a future.

What happens when the human being lives in desired and unwanted jobs and unfinished studies that causes an emotional upset, affecting their academic performance due to stress?; What is it there for? What are the intentions? the motivation is lost, the purposes and the possibility of enjoying is lost, there is no full awareness of what happens in the academic process, the purpose or objectives of being in the school-work space are distorted.

Academic performance is a process that is strengthened as students are devoting enough time to study but when they devote much of their time to work is very likely to affect their academic performance. The basic factors that influence academic performance may be due to sociodemographic conditions, personal reasons (family problems, employment, income, health), motivational, cognitive and emotional factors such as fatigue or stress that intervene in the concentration and attention of the student. The human project is characterized by a constant search, where the possibilities are innumerable; spaces of healthy coexistence, spaces of triumph, clean and strengthened spaces. Anxiety does not let see, nor understand, nor understand, emptying us to the sterile process of disinterest, loss of personal organization, aggressive behavior, anger, not heard.

How will workers and students, when they develop these functions without affecting their academic performance? This will be possible when their awareness of transcendence is open to the processes of personalization, responsibility, organization and recognition, of concrete actions that motivate students to achieve a greater academic performance, also dedicate some hours of work. There are no "schools of life" that teach what is essential, what is really authentic and necessary and in the hypothetical case that these schools were opened, it is probable that teachers were lacking (no one can teach what they do not know or do not know), and of students (the accentuated and profound indifference prevents the interest to learn or to change). To some extent, before, the "schools of life" were the home, the family, and the educational, cultural, religious, and even labor institutions.

Today, these institutions are deteriorated because the men who constitute them are disoriented and this does not allow the anchoring or sedimentation necessary to achieve a sincere and authentic existential location. One of the most serious and immediate consequences of this dislocation is the loss of self-esteem. Then, to educate is to gradually achieve that each one manifests or externalizes what it truly is (unveiling the authentic being), by means of a personalization able to balance it harmonically with the environment in which it lives, in order to have a real existence and not alienated, free of all dehumanization. [8].

Arriving at school should be a quiet place where what is done has to do with well-being, overcoming and recognizing, because ultimately it is what makes young people stand as students, not just an action but a attitude.

As teachers of the Autonomous University of Guerrero, we note that more and more are the number of students who are in need of finding a job to pay for their studies and / or to contribute to family expenses. These young people are identified by the yawns they try to avoid and / or because they fall asleep during class time, because they always look tired, because they arrive late for classes or leave the classroom before their class schedule ends. to run away to his job. These are the young people who study and, at the same time, work to be able to maintain their studies or to be able to help financially in the family expenses.

The particularities presented by the young people who study and work are very evident. The student who studies and works dedicates less time to their homework, has difficulty concentrating and mastering their attention, their performance is different, they try to get tasks and jobs out of order and without clarity, always due to lack of time and no capacity. They are young people who always put the time they dedicate to their work as an excuse.

Given the need to have an income, this causes that young people are not linked with their education to complete and take advantage of it, or with the labor market, concluded the Organization for Economic Cooperation and Development (OECD). In the Panorama of Education 2014 report, the OECD, [9] indicates that Mexico is the only one among the 
34 member countries where young people between 15 and 29 years of age spend more time in some work before completing or reinforce their superior and superior studies.

Low student performance has long-term consequences for both individuals and countries. Students with low performance show less perseverance, motivation and selfconfidence, which prevents the development of the person, and at the same time, the development of a society.

In this context, young people tend to diminish the illusion and desire that they have towards a professional future, originating with this a high probability of dropping out of school. That is why the desertion, the student lag and the low rates of terminal efficiency are among the most complex problems that challenge Higher Education Institutions. Starting higher education studies, is the aspiration of many young people, however, for some their economic situation represents an impediment or for others, there is the option to work and study at the same time. Thus, having a job during the day and studying in the evening is a very common alternative nowadays.

One of the most important aspects in the teaching-learning process is undoubtedly the academic performance of students. The academic performance of university students constitutes an important factor in the issue of quality in higher education, since it is an indicator that allows an approximation to the educational reality. Several authors agree that academic performance results from learning derived from the teacher's didactic activity and produced in the student. The performance according to Pizarro (cited by Reyes, 2003, 2) is understood as: "a measure of the corresponding or indicative capacities that show, in an estimated form, what a person has learned as a result of an instruction or training process."

From a humanistic approach, for Martínez-Otero, academic performance is "the product that students give in schools and that is usually expressed through school grades" [10] while for Pizarro (1985) describes the academic performance "as a measure of the respondent or indicative capacities that show, in an estimated way, what a person has learned as a result of an instruction or training process". [11].

Carrasco defines academic performance as the expression of skills and psychological characteristics of the student developed and updated through the teaching-learning process that allows you to obtain a level of performance and academic achievements over a period, which is synthesized in a final qualifier (quantitative in most cases that evaluates the level reached. [12].

The authors Palacios, J. and Rodrigo, M, after making a comparative analysis of various definitions of academic performance, conclude that there is a double point of view, static, that comprises the product derived from the learning generated by the students and that expresses a behavior of use and dynamic, which responds to the learning process linked to the ability and effort of the student.

For Tonconi, academic performance is an indicator of the level of learning achieved by the student, represents the level of effectiveness in achieving the curricular objectives for the various subjects. This definition refers to how academic performance expresses the degree of achievement that students have had in the assimilation and understanding of teaching content; that is, what the student has learned as a result of a process of instruction or training, and defines in one way or another the success or failure in the study. [14].

Exposed the previous theories about the academic performance, it is appreciated that as such, reference is made to the measurement of knowledge of the learning achieved in the classroom. However, if you intend to conceptualize academic performance only from a grade, that is, a student with good academic performance is one who obtains grades higher than 8 on a scale of 1 to 10 in the exams, we would be leaving out other aspects that are part of the students, such as attending classes, arriving punctually to classes, making and delivering homework and assignments in a timely manner, studying to present exams, understanding classes, etc.

While it is true that academic performance can vary according to personality, motivation, skills, interests, study habits, self-esteem or teacher-student relationship, it is also true that more and more students of education superior and due to the economic crisis that is experienced in the country, they are in need of work to be able to sustain their studies and / or to contribute economically in the sustenance of their family.

For this, it is important to also consider that Mexicans are the workers who work the most hours during the year. Their workday includes 2,222 hours (2 thousand 327 people who have more than one job), but they also have the lowest salaries (12 thousand 850 dollars per year), according to the OECD study, [15] Costa Ricans, South Koreans and Greeks are among those who work the most. An amount much higher than the thousand 789 of the United States, thousand 729 of Japan or thousand 689 of Spain, not to mention the thousand 371 of Germany. The OECD average is 1,770 hours per year.

In other words, in Mexico we work many more hours than in all the other OECD countries and much more than in the main world economies. Sadly this does not mean much more than that and as proof, Greece, in the midst of a crisis, ranks fourth. It should even be noted that in the top places of the list are countries with emerging or weak economies, while those countries where living standards are very high are to the bottom.

\section{Justification}

In the UAGro there are different sectors of students with different economic and social problems each of them, such as, for example, students who do not need to work during their studies, single mothers, married men and women who need to work, but also with jobs in which they are exposed to change their shift, or even city, then the studies are in the background, are we really promoting educational contexts appropriate to the needs of the student? Have we asked them what their projects and common problems are?

The authors of this research work consider that in the face 
of the demands of adopting an educational model, of reviewing study plans, evaluating teachers, offering student mobility, scholarships, professional practices, all with the purpose of achieving a quality education, as teachers we are obliged to attend to those students whose academic activities can take a back seat because they dedicate more time and attention to their jobs and consequently suffer from overwhelm due to the different responsibilities, anxiety, inability to concentrate, lack of learning skills and that can favor school dropouts. We believe that this will be possible through the Institutional Program of Tutoring as the space where strategies should be designed to identify and respond opportunely to problems faced by students in their academic education and that prevent them from leaving their studies.

Therefore, the objective of this research was to analyze the impacts of the workday on the academic performance of 3rd and 4th grade students of the Schools of Psychology, LawAcapulco, Sociology and Tourism, case Universidad Autónoma de Guerrero, México.

\section{Materials and Methods}

In the present research we worked with the mixed approach (quantitative and qualitative). The establishment of a mixed approach (descriptive and correlational) allowed the design of this research, through the most appropriate methods and techniques that allowed fundamentally the analysis of the data and information that allow the testing.

In descriptive and correlational research the purpose is to describe situations and events. That is, to say how a certain phenomenon is and manifests, which had the purpose of determining the degree of relationship or association existing between two or more variables. In this sense, and under a descriptive and correlation study, we sought to present the reality about the impacts of the workday on the academic performance of the students of the Schools of Psychology, Sociology Law and Tourism, case Universidad Autónoma de Guerrero.

The survey technique widely used as a research procedure was applied, since it allows to obtain and elaborate data in a fast and efficient way, by means of which a series of data of a sample of a population is collected and analyzed, from which it is tried to explore, describe, predict and / or explain a series of characteristics. We consider that through this technique the information is collected in a standardized way by means of a questionnaire that allows to make intergroup comparisons.

The questionnaire was divided into three parts: 1. Personal information 2. School information and 3. Employment information of students of the Schools of Psychology, Sociology, Law and Tourism of the Autonomous University of Guerrero, which allowed to know the following personal information Of the 371 surveys applied to students in the four Schools, the predominant gender was female, with 228 women surveyed, while the masculine corresponded to 143 respondents; Regarding the ages of the 371 respondents, it was observed that their ages fluctuated in a range of between 19 to 66 years, being the ages between 20 to 24 years the most frequent; as regards the marital status of the 371 interviewees, 28 stated that they were married, 25 live in a free union and 318 are single; As for the number of children, of the 371 interviewed 67 reported having children while 304 reported not having children.

In the second part of the survey referring to the school information of the students surveyed from the four schools, the results were as follows: of the 371 surveys applied, the highest number corresponded to the School of Law-Acapulco with 219 students, in second place the School of Psychology with 91 students, in third place the Superior School of Sociology with 41 students and in fourth place the Faculty of Tourism with 20 students.

\section{Results and Discussion}

The School of Law is one of the institutions of the Autonomous University of Guerrero with a higher number of enrollment, with a current student population of 2,200 students explains the largest number of surveys applied.

Table 1. School Information.

\begin{tabular}{llllll}
\hline & & Frequency & Percentage & Valid percentage & Accumulated percentage \\
\hline \multirow{4}{*}{ Valid } & LAWS & 219 & 59.0 & 59.0 & 59.0 \\
& PSYCHOLOGY & 91 & 24.5 & 24.5 & 83.6 \\
& SOCIOLOGY & 41 & 11.1 & 11.1 & 94.6 \\
& TOURISM & 20 & 5.4 & 5.4 & 100.0 \\
& Total & 371 & 100.0 & 100.0 & \\
\hline
\end{tabular}

Regarding the grades of the students surveyed, the results showed that of the 371 surveys applied in the four schools, 200 students attend the fifth grade while 171 attend the seventh grade.

Table 2. Grade

\begin{tabular}{lllll}
\hline & & Frequency & Percentage & Valid percentage \\
\hline & 501 & 29 & 7.8 & 7.8 \\
Valid & 502 & 30 & 5.1 & 8.1 \\
& 503 & 21 & 5.1 & 5.7 \\
& 504 & 19 & 5.9 & 5.1 \\
& 505 & 22 & 8.6 & 5.9 \\
\hline
\end{tabular}




\begin{tabular}{llll}
\hline & Frequency & Percentage & Valid percentage \\
\hline 507 & 22 & 5.9 & \\
508 & 25 & 6.9 & 6.7 \\
701 & 22 & 5.9 & 5.9 \\
702 & 49 & 13.2 & 13.2 \\
703 & 17 & 4.6 & 4.6 \\
704 & 15 & 1.6 & 4.0 \\
705 & 6 & 9.7 & 1.6 \\
706 & 36 & 4.3 & 9.7 \\
707 & 16 & 2.7 & 4.3 \\
708 & 10 & 100.0 & 2.7 \\
Total & 371 & & 100.0 \\
\hline
\end{tabular}

In relation to the turn attended by the school, the 371 students of the four schools, 208 students study in the afternoon shift and 163 in the morning shift. The lifestyle and needs of students at the time of their studies are varied and are decisive in deciding the shift in which they will attend school, from having to do a job, take charge of the home, take care of family members or Do other activities that, sometimes, are only allowed during certain times.

Table 3. Turn.

\begin{tabular}{llllll}
\hline & & Frequency & Porcentage & Valid percentage & Accumulated percentage \\
\hline \multirow{3}{*}{ Valid } & MORNING & 163 & 43.9 & 43.9 & 43.9 \\
& EVENING & 208 & 56.1 & 56.1 & 100.0 \\
& Total & 371 & 100.0 & 100.0 & \\
\hline
\end{tabular}

In the third part of the survey regarding the labor information of the students of the four schools, the surveys showed the following results:

Regarding the first question about whether they work mainly to: a) cover their studies 258 students chose this option; b) support their parents with family expenses 67 students chose this option and c) to obtain work experience 46 students selected this circumstance. Being the option a) the highest in relation to the other options. 258 students of the 371 respondents see themselves in need of work to support their studies, a situation that is understood due to the socioeconomic inequality prevailing in Mexico. Students need to combine study and work, however, both roles can be a risk factor that precedes school dropouts.

Table 4. You work mainly for.

\begin{tabular}{llll}
\hline & Frequency & Porcentage & Valid percentage \\
\hline pay for your studies & 67 & 18.1 & 18.1 \\
Support your parents with family spending & 46 & 12.4 & 12.4 \\
To obtain work experience & 371 & 100.0 & 100.0 \\
\hline
\end{tabular}

In turn question two of the survey on how much time your workday comprises, the data thrown were the following: 262 of the students said they worked more than 8 hours a day, which exceeds the maximum work day allowed by law and that Justify the analysis of the OECD, which included 38 countries, showed that Mexicans $(2,225$ hours / year) and Costa Ricans $(2,212)$ have the longest working hours in the world. (UNIDAS, 2017).

Table 5. How much time does your workday comprise?

\begin{tabular}{|c|c|c|c|c|c|}
\hline & & Frequency & Porcentage & Valid percentage & Accumulated percentage \\
\hline \multirow{4}{*}{ Valid } & More than $8 \mathrm{hrs}$ & 262 & 70.6 & 70.6 & 70.9 \\
\hline & More than 10 hrs. & 73 & 19.4 & 19.4 & 90.3 \\
\hline & More than $12 \mathrm{hrs}$. & 36 & 9.7 & 9.7 & 100.0 \\
\hline & Total & 371 & 100.0 & 100.0 & \\
\hline
\end{tabular}

Considering the time they dedicate to perform their tasks and academic work, of the 371 participants in the sample, $69.3 \%$ have only two hours for these activities, because it is the longest time that can be placed in the school environment within the occupations that he plays as a student and provider.

Table 6. How much time do you spend to complete your assignments and academic work?

\begin{tabular}{|c|c|c|c|c|c|}
\hline & & Frequency & Porcentage & Valid percentage & Accumulated percentage \\
\hline \multirow{4}{*}{ Valid } & More than $2 \mathrm{hrs}$ & 257 & 69.3 & 69.3 & 69.3 \\
\hline & More than $4 \mathrm{hrs}$ & 96 & 25.9 & 25.9 & 95.1 \\
\hline & More than $6 \mathrm{hrs}$ & 18 & 4.9 & 4.9 & 100.0 \\
\hline & Total & 371 & 100.0 & 100.0 & \\
\hline
\end{tabular}


According to the data of question four on how many hours sleep daily can be seen in the table that $55 \%$ of respondents sleep from 6 to more hours, compared to this and data from the WHO (2014) Sleeping little can affect health . The WHO recommends resting at least 6 hours a day.

Table 7. How many hours do you sleep daily?

\begin{tabular}{lllll}
\hline & & Frequency & Porcentage & Valid percentage \\
\hline \multirow{4}{*}{ Valid } & More than 4 hrs. & 133 & 35.8 & 35.8 \\
& More than 6 hrs & 206 & 55.5 & 55.5 \\
& More than 8 hrs. & 32 & 8.6 & 8.6 \\
& Total & 371 & 100.0 & 100.0 \\
\hline
\end{tabular}

In relation to question five of the survey about whether students deliver punctually their assignments and academic work, of the 371 students surveyed, 161 answered that always, 204 regularly and 6 answered never. In the case of the 204 students who responded regularly, it is important to provide students through the Institutional Tutoring Program with the necessary techniques to effectively organize their time and learn to recognize that their obligations and responsibilities are as important as personal needs.

Table 8. Deliver your assignments and academic assignments on time?

\begin{tabular}{lllll}
\hline & & Frequency & Porcentage & Valid percentage \\
\hline \multirow{3}{*}{ Valid } & Forever & 161 & 43.4 & 43.4 \\
& Regularly & 204 & 55.0 & 55.0 \\
& Never & 6 & 1.6 & 1.6 \\
& Total & 371 & 100.0 & 100.0 \\
\hline
\end{tabular}

In question six related to the activities they do in their free time, the largest number of students surveyed stated that their main activity is reading, in order to complement the lack of attention they have for the hasty activities they have to do, in second position with a frequency of 38 participants performing tasks, and third with 34 participants the option to sleep, these are the three main activities that students develop.

Table 9. What activities do you do in your free time?

\begin{tabular}{lllll}
\hline & Frequency & Porcentage & Valid percentage & Accumulated percentage \\
\hline READ & 39 & 10.5 & 10.5 & 69.3 \\
HOMEWORK & 38 & 10.2 & 10.2 & 93.5 \\
SLEEP & 34 & 9.2 & 9.2 & 29.1 \\
\hline
\end{tabular}

With respect to question seven on whether they are awake to perform their tasks or academic work, of the 371 respondents, 326 answered yes, attaching these $87.9 \%$ of the total sample, being that 44 answered no and 1 student answered that some times. The majority of the students surveyed are kept awake to perform their tasks, a situation that generates alert since, as previously described, not resting in the proper manner causes damage to physical and mental health.

Table 10. Do you wake up to do your homework or academic work?

\begin{tabular}{llllll}
\hline & & Frequency & Porcentage & Valid percentage & Accumulated percentage \\
\hline \multirow{4}{*}{ Valid } & Yes & 326 & 87.9 & 87.9 & 87.9 \\
& No & 44 & 11.9 & 11.9 & 99.7 \\
& Sometimes & 1 & .3 & .3 & 100.0 \\
\hline
\end{tabular}

Regarding question eight on whether stress and stress generate their tasks or academic work, of the 371 respondents 269 answered yes, 102 answered no, they are the result of an accelerated pace of life at present. Each person is affected differently, because each of them has a psychological pattern that makes them react differently to others, that is, each of us is different from the others and therefore we act and manifest ourselves different way.

Table 11. Does stress and stress generate your tasks or academic work?

\begin{tabular}{lllll}
\hline & & Frequency & Porcentage & Valid percentage \\
\hline \multirow{3}{*}{ Valid } & Yes & 269 & 72.5 & 72.5 \\
& No & 102 & 27.5 & 27.5 \\
& Total & 371 & 100.0 & 100.0 \\
\hline
\end{tabular}

The next aspect is about whether it is perceived to have problems of attention and concentration in the classes, of which $55.3 \%$ say not having them this data is supported by a frequency of 205 participants, instead 165 participants mention if they have them and that these affect their performance labor, professional and personal. 
María del Rocío García Sánchez et al.: Impact of the Work on the Academic Performance of the Students of Higher Education of the Autonomous University of Guerrero, México

Table 12. Do you have attention and concentration problems in the classes?

\begin{tabular}{llllll}
\hline & & Frequency & Porcentage & Valid percentage & Accumulated percentage \\
\hline \multirow{4}{*}{ Valid } & Yes & 165 & 44.5 & 44.5 & 44.5 \\
& No & 205 & 55.3 & 55.3 & 99.7 \\
& Sometimes & 1 & .3 & .3 & 100.0 \\
& Total & 371 & 100.0 & 100.0 \\
\hline
\end{tabular}

Taking into account if it is considered to give enough time to the study for the presentation of exams, $63.9 \%$ of the sample express not to offer this time, this result being greater than the total half of the sample.

Table 13. Do you consider that you dedicate enough time to study and present your exams?

\begin{tabular}{lllll}
\hline & & Frequency & Porcentage & Valid percentage \\
\hline \multirow{3}{*}{ Valid } & Yes & 134 & 36.1 & 36.1 \\
& No & 237 & 63.9 & 63.9 \\
& Total & 371 & 100.0 & 100.0 \\
\hline
\end{tabular}

When asked eleven about whether they have any study technique to prepare and present their exams 184 answered yes and 185 answered no, in this aspect we consider as teachers that many young students do not know what the study techniques are as an elementary part of great importance since it would allow them to order work, prioritize, take advantage of available resources in a better way and also allow the development of new techniques and ways of facing knowledge in the future. Knowledge about these study techniques can be offered to students from the Institutional Tutoring Program.

Table 14. Do you have any study technique to prepare and present your exams?

\begin{tabular}{llllll}
\hline & & Frequency & Porcentage & Valid percentage & Accumulated percentage \\
\hline \multirow{4}{*}{ Valid } & Yes & 184 & 49.6 & 49.6 & 49.6 \\
& No & 185 & 49.9 & 49.9 & 99.5 \\
& Sometimes & 2 & .5 & .5 & 100.0 \\
& Total & 371 & 100.0 & 100.0 \\
\hline
\end{tabular}

In question twelve about whether the circumstance of choosing between work and school came up, 266 students chose the school, while 106 opted for the job, the latter surely as we have explained at the beginning of the investigation, the crisis economic situation in which Mexico finds itself and before the fall of the purchasing power of the salary, it has become necessary to increase the economic income in each family and it is precisely the young people who decide to work to contribute with the family expenditure. The desertion in higher education is one of the most worrying problems because it has economic, labor, emotional and social consequences that affect both the student and parents, as well as the institution and the State.

Table 15. If the circumstance of choosing between work and school were to arise, you would opt for.

\begin{tabular}{lllll}
\hline & & Frequency & Porcentage & Valid percentage \\
\hline \multirow{3}{*}{ Valid } & School & 266 & 71.7 & 71.7 \\
& Work & 105 & 28.3 & 28.3 \\
& Total & 371 & 100.0 & 100.0 \\
\hline
\end{tabular}

\section{Conclusions}

When dealing with students who develop two joint activities such as work and study, they do not take advantage of the same time or have the same motivation and learning style. Teachers through the Institutional Tutoring Program have to promote the development of skills for the search of information, for the solution of problems for individual and collective work

The work of the teacher should not only focus on student learning, but also as a tutor should serve as the axis for the transformation of educational practices, also in the construction of the student's school career through individual intervention strategies, promote learning environments that allow acquiring and strengthening skills and significant abilities in students, and of course encourage the development of values and attitudes that govern the behavior of students in their professional and personal lives in the different situations that they have to face.

The real and responsible application of tutoring should allow knowing the individual characteristics, the social and family environment in which they develop, personal interests, professional and work expectations and life projects of young people, and thereby establish strategies that they favor the formation of people in an integral way, which allows them to unravel competitively in their professional, personal environment, with social responsibility and respect for ethical and moral values.

The support and participation of teachers through the Institutional Program of Tutoring with a focus on the humanism of the Schools of Psychology, Sociology and Tourism Law of the Autonomous University of Guerrero will 
be fundamental to the extent that it assumes preponderantly, under the protection of a job in tutorials, benefiting the students.

One of the most important contributions of the research has been the identification of other future lines of research, the short-term creation of a manual for teachers that serves as a tool or auxiliary guide in their role as tutors, that is, information on teaching strategies to facilitate student learning, to clarify goals and planning of academic tasks, as well as support throughout the students' academic trajectory, study processes and techniques, provide help and advice beyond academic matters, such as teaching of work habits, organizational skills and establishment of priorities, among other things.

One drawback in this research work was the fact that it was not possible to expand the field of research, that is, to apply the surveys in other areas of higher education at the Autonomous University of Guerrero, México, for example in the area of science health, engineering and technology, natural and exact sciences, etc., due to the hurry of time.

\section{Special Thanks}

Our sincere thanks for the Psic. Rosa Maria de la Cruz de la Cruz, as well as the students of the Higher School of Psychology of the UAGro., Evelyn Cuevas Cortes and José Antonio Hernández Guzmán who generously collaborated in the capture of the surveys. At three, thank you very much.

\section{References}

[1] D. T. y. H. Ullman, Juventud: realidades y retos para un desarrollo con igualdad, Santiago: CEPAL, 2015.

[2] S. d. E. Publica, «Subsecretaría de Educación Media Superior,» 9 Marzo 2012. [En línea]. Available: http://www.sems.gob.mx/work/models/sems/Resource/10787/ 1/images/Anexo_6Reporte_de_la_ENDEMS.pdf. [Último acceso: 22 0ctube 2018].

[3] N. I. F. L. STUDIES, «World of work report 2012: Better jobs for a better economy,» 2012. [En línea]. Available: https://www.ilo.org/wcmsp5/groups/public/---dgreports/--- dcomm/---publ/documents/publication/wcms_179453.pdf. [Último acceso: 22 octubre 2018].

[4] P. d. 1. N. U. p. e. Desarrollo, «Informe Regional sobre Desarrollo Humano,» 2010. [En línea]. Available: http://hdr.undp.org/sites/default/files/rhdr-2010-rblac.pdf. [Último acceso: 22 octubre 2018].

[5] C. C. Mario, EMPLEO DIGNO DISTRIBUCION DEL INGRESO Y BIENESTAR, Recomendaciones para un nuevo modelo., Mexico: Editorial: CASA JUAN PABLOS , 2012.

[6] T. Carlos, Sobre la desigualdad en México, Mexico: Universidad Nacional Autnoma de Mexico, 2012.

[7] S. Miguel, «POBREZA Y DESIGUALDAD EN MÉXICO,» El Trimestre Económico, Vols. \%1 de \%2vol. LXXII (4), , $\mathrm{n}^{\circ}$ núm. 288, pp. pp.913-931, 2005.

[8] P. Antonio, «ESTRÉS - DISTRÉS,» Revista Argentina de Psiquiatría Biológica, vol. V, nº 1, p. 300, 1999.

[9] O. p. 1. C. y. e. D. Económicos, «Panorama de la educación Indicadores de la OCDE 2017,» 2017. [En línea]. Available: http://www.fundacionsantillana.com/2018/01/10/panoramade-la-educacion-2017-indicadores-de-la-ocde-2/. [Último acceso: 22 octubre 2018].

[10] M.-O. P. Valentín, Los adolescentes ante el estudio: causas y consecuencias del rendimiento académico, Madrid: Fundamentos, 1997.

[11] P. R. J. Rosa, Rasgos y actitudes de profesor efectivo, Chile: Pontificia Universidad Católica de Chile, 1986.

[12] B. C. J. y. G. D. J. Luis, La recuperación educativa: problemas y soluciones, Madrid: Bruño, 1972.

[13] J. y. R. M. Palacios, La familia como contexto de desarrollo humano., Madrid: Alianza Editorial., 2003.

[14] T. Q. Juan, «FACTORES QUE INFLUYEN EN EL RENDIMIENTO ACADÉMICO Y LA DESERCIÓN DE LOS ESTUDIANTES DE LA FACULTAD DE INGENIERÍA ECONÓMICA DE LA UNA-PUNO, PERIODO 2009,» Cuadernos de Educación y Desarrollo, vol. 2, n ${ }^{\circ}$ 11, p. 29, 2010.

[15] O. p. 1. C. y. e. D. Económicos, «Organización para la Cooperación y el Desarrollo Económico», 2015. [En línea]. Available: https://www.oecd.org/mexico/mexico-politicasprioritarias-para-fomentar-las-habilidades-y-conocimientosde-los-Mexicanos.pdf. [Último acceso: 22 0ctubre 2018]. 